\title{
Developing Cognitive Ability to Matching Numbers and Symbol Using a Combination of Models, Methods, and Media Learning
}

\author{
Raydesi Erviana *, Karyono Ibnu Ahmad, Nina Permata Sari \\ Master Program of Early Childhood Teacher Education, Universitas Lambung Mangkurat, Banjarmasin \\ 70123, Indonesia
}

Article history:

Submission May 2020

Revised June 2020

Accepted June 2020

*Corresponding author:

E-mail: raydessi2020@gmail.com

\begin{abstract}
This study aims to determine the activities of teachers, children, and the results of children's cognitive development. The approach used is a qualitative research approach and with the type of classroom action research, which was carried out in 4 meetings, research settings in group A children in Aisyiyah Kindergarten, Kecamatan Satui, Kabupaten Tanah Bumbu, amounting to 15 children. Data collection techniques using observation, documentation and interviews and assessment of aspects of cognitive development. The results showed that the teacher's activity at the 4 th meeting with a score of 36 in the category of Very Good. Children's activities at the 4th meeting with a percentage of $87.5 \%$ the category is very active and the results of cognitive development at the last meeting reached $84 \%$ of children who succeeded by getting $\star \star \star$ and $\star \star \star \star$. Based on the results of the study it can be concluded that the application of a combination of Picture and picture models, talking sticks, with the method of conversing, demonstration and media card numbers can develop the activities of teachers, children and cognitive development results with very good and very active developing categories.
\end{abstract}

Keywords: cognitive ability, models, methods, media learning

\section{Introduction}

Education is a very important thing for all children to get, because education is one of the assets that must be owned by every individual to achieve success in his life. National education functions to develop capabilities and shape the dignified character and civilization of the nation in the context of the intellectual life of the nation (Sujiono, 2013).

The Indonesian National Education System as explained in the Law on the National Education System is an integrated whole of all types, standards and educational activities related to each other to strive to achieve the goals of $\mathrm{Na}$ tional education. Education in this context serves to develop capabilities and improve the quality of life and human dignity through improving the quality of life and human dignity through increasing intelligence and development.

PAUD Standards are an integral part of the National Education Standards as mandated in Government Regulation Number. 19 of year 2005 concerning National Education Standards that are formulated taking into account the characteristics of PAUD administration. The standard level of development achievement contains the rules of growth and development of early childhood from birth to the age of six years.

The level of development achieved is the actualization of the potential aspects of the devel-

How to cite:

Erviana, R., Ahmad, K. I., \& Sari, N. P. (2019). Developing cognitive ability to matching numbers and symbol using a combination of models, methods, and media learning. Journal of K6, Education, and Management, 2 (4), 271 - 282. doi: 10.11594/jk6em.02.04.02 
opment of religious and moral, physical, cognitive, linguistic, and social emotional values which are expected to be achieved by children at each stage of their development, not a level of achievement of academic skills (Ministry of National Education, 2009).

The student or child is a student, he is not just a object of the education that is ready to be filled with knowledge from the teacher's brain as well as a bottle that is ready to be filled with full water. As a student subject he has self-autonomy that wants to be recognized in accordance with the potential strengths and weaknesses he has (Suriansyah \& Aslamiah, 2011).

Cognitive development is closely related to logos-mathematical and naturalist intelligence. The logical-mathematical intelligence stimulus will encourage cognitive development, especially in terms of the ability to think logically, process information, thinking capacity, memorization, reasoning, concept acquisition, classification, problem solving, and concentration (Musfiroh, 2012).

In the development of cognitive aspects in kindergarten, numbers are a concept that is learned. The importance of the concept of numbers is given at kindergarten age because the concept of numbers is one of the concepts children learn when they are at a higher level of education. In addition, the importance of the concept of numbers is taught to kindergarten children in order to foster children's love and preference for numbers. Numbers is one concept that is not separate from everyday life.

The role of teachers and parents is very important in children's development, especially in understanding the child's golden period as early as possible (Amalia \& Khoiriyati, 2018). When conducting this research, the teacher found many benefits, including the teacher being able to understand that children will be more active when children are directly involved in these activities, the use of interesting media will foster children's attention, by directly training the child to gain his own experience.

Early childhood education teacher should provide the students with well-scaffolded instruction that can support the students' social development, emotional, academic, habits, and mindsets (Darling-Hammond, Flook, CookHarvey, Barron, \& Osher, 2020). A teacher is expected to provide a good environment to be able to foster student development optimally in the learning process (Suriansyah, Aslamiah, Noorhafizah, \& Sulaiman, 2009).

How to learn early childhood is different from the way of learning adults and older children, namely through playing and using media tools such as touching, building and breaking down, filling and emptying, stringing, listening to stories and singing, playing roles, and so on (Wahyudi, 2015). Learning in kindergarten is carried out with the principle of "learning while playing" in accordance with the development of students this is because at the age of 4-6 years children are still in playtime so that all activities carried out in kindergarten prioritize play activities (Aslamiah, 2011). With learning activities while playing, students are expected to be able to develop all their abilities.

Mathematics is a discipline that can improve the ability to think, argue, solve everyday problems and problems that occur in the world of work and contribute to the development of science and technology. With Mathematics, students are trained to solve problems by thinking critically, carefully and carefully (Suriansyah \& Mahriati, 2016).

Mathematical concepts is an important basis for thinking in solving mathematical problems and everyday problems (Hadi \& Kasum, 2015). With a good understanding of mathematical concepts, students will easily remember, use, and rearrange a concept that has been learned and can solve various variations of mathematical problems.

Children aged three, four and five years can learn to like thinking in mathematics, if they learn to enjoy mathematics, learning while playing is one of the strategies to make young children enjoy or enjoy math. Therefore, understanding of numbers is the basis of a strong foundation for children in developing children's cognitive abilities at a later stage. So that children are expected to be able to recognize numbers and symbols of numbers, match symbols of numbers 1-10, designate symbols of numbers 1-10, imitate symbols of numbers 1 10 . From the results of observations made in 
group A Aisyiyah Kindergarten, data obtained the number of children there are 15 children consisting of 9 boys and 6 girls. From the number of children proficiency level results from the assessment of cognitive development namely matching numbers and symbols are obtained as follows: 1 child $(6.7 \%)$ gets $(\star \star \star \star)$ which means that it develops very well (BSB), 2 children $(13.33 \%)$ gets $(\star \star \star)$ ) which means it develops as expected (BSH), 9 children (60\%) get $(\star \star)$ which means it starts to develop (MB) and 3 children $(20 \%)$ get $(\star)$ in the sense undeveloped (BB). So, from the observations of the results of children's learning assessment can be said to have not been successful because there are 12 children ( $80 \%)$ of the total number of children who are still underdeveloped and begin to develop. So, we can conclude that this is a problem.

Based on the desired expectations and observations in the field found a problem that cognitive aspects in kindergarten have not yet developed, especially in the field of development achievements matching numbers and symbols of numbers, there are still children who have not been able to match correctly. From these problems it is known that the cause of the problem is the teacher is less able to design strategies and models of learning that are efficient, effective and interesting, the teacher only uses old methods in conveying material numbers and symbols of numbers, the learning used is still dominated by the teacher so that makes the child feel bored and less active in learning, the media used by the teacher are less attractive so that makes children feel bored.

If this is left unchecked, then what is expected is not achieved and will become an obstacle to the ability to recognize numbers and symbols of child numbers until the future, because if the child's ability to recognize numbers and symbols of these numbers is developed early and in accordance with the level its development will affect the cognitive aspects of children and children's achievement at the next level of education because knowing symbols is the basis of mathematical ability. One way that can be taken to activate the child is to use a combination of learning that can motivate, arouse interest, activeness and can develop children's abilities in learning by making them directly involved in learning, because then they will easily understand the lessons learned taught (Fatmasari, Darmiyati, \& Sulaiman, 2015).

Seeing the obstacles that exist in the field and so that children can reach the stages of development, the researchers tried one way and strategy to help improve children's ability to match numbers and symbols of numbers well, use a combination of picture and picture models, talking sticks with conversational methods, demonstrations and number card media.

The Picture and Picture learning model is a learning model that uses pictures and is paired / sorted into a logical sequence. These images become a major factor in the learning process. So, before the learning process the teacher has prepared pictures to be displayed either in the form of cards or in the form of stories in large sizes (Pradina \& Hastuti, 2017). The advantage of the Picture and Picture model is that the material taught is more directed because at the beginning of learning the teacher explains the competencies that must be achieved and the material briefly in advance. Children catch teaching material faster because it shows pictures about the material being learned. Can increase the child's reasoning or thinking power because the child is told by the teacher to analyze the picture. Can increase children's responsibility, because the teacher asks why children sort the picture. Learning is more memorable, because children can observe directly the pictures that have been prepared by the teacher (Pradina \& Hastuti, 2017).

Talking Stick Model is a group learning model with the help of a stick, the child holding the stick first answers questions from the teacher after the child learns the subject matter, then the activity is repeated continuously until all children have a turn to answer questions from the teacher (Aqib, 2014). Talking Stick is a learning model that is useful for training the courage of children in answering and speaking to others, while the use of sticks in rotation as a medium to stimulate action more quickly and accurately while measuring the child's ability to understand material (Maufur, 2009). The advantage of the Talking Stick model is that it can create a pleasant atmosphere, so that children are not tense and can 
learn well, so that children feel motivated and happy to be able to participate in learning activities and can master the learning material. Once the work can be two learning, namely learning to sing and the material being taught. Children become motivated to be creative in a variety of songs (Aqib, 2014).

The method of conversing is one form of interpersonal communication. Communicating is a two-way process. For the occurrence of communication in conversation requires listening skills and speaking skills. For effective conversations, learning to speak and learn to listen are equally important. There are three things that must be done in interpersonal communication namely; (1) Measuring comprehension that is heard with certainty; (2) If the message conveyed is not clear, he can inform the speaker; (3) the speaker can determine the additional information needed in order to receive the message (Moeslichatoen, 2004).

Conversation is a process of finding out or confirming or matching the knowledge that a child already has with the new knowledge that is being learned. The purpose of conversing is to improve the development of Early Childhood which includes aspects of development; (1) Cognitive; (2) Language; (3) Social; (4) Emotional; (5) Self-concept. Children develop a variety of knowledge in various themes that will spur various aspects of child development. The more knowledge gained from various themes that are determined, the broader the knowledge of children about themselves, family, and school and so on can process the maturity of thinking.

Emphasizing listening activities through lectures and observing activities through demonstrations so as to help students who are suitable learn in these ways. Provides a challenge to consider the gap between theory (what should be) and observation (what needs to happen). Can be applied effectively in large classes or small classes. Students can know the learning objectives clearly.

Demonstration method is a method of presenting learning by demonstrating and showing students about a certain process, situation and object, whether actual or just an imitation.
As a method of presentation, the demonstration is inseparable from the verbal explanation by the teacher. Although in the process of demonstrating the role of students only pay attention, but the demonstration can present explanatory material more concretely. In learning strategies, demonstrations can be used to support the success of expository and inquiry learning strategies (Sanjaya, 2013).

The advantage of the demonstration method is that verbalism can be avoided, because students are told to pay close attention to the lesson explained. The learning process will be more interesting, because students not only listen, but also see events that occur. By observing directly, the child will have the opportunity to compare theory and reality. While the weakness of the demonstration method requires more thorough preparation, because without adequate preparation the demonstration can fail so that this method can no longer be effective. Demonstrations require adequate equipment, materials and premises. Demonstrations require special abilities and skills of teachers, so teachers are required to work more professionally.

From the description above, the combination of learning models with learning methods is expected to develop children's abilities, especially in the cognitive aspects of children with number card media that will make learning more meaningful, children are not easily bored, more interested in participating in learning, children feel happy, active and enthusiastic when taking lessons.

Based on the explanation above, the researcher is interested in raising the title "Developing Children's Cognitive Abilities in Matching Numbers and Symbols Using a Combination of Learning Models, Methods and Number Card Media in Group A Children in Aisyiyah Kindergarten Kecamatan Satui Kabupaten Tanah Bumbu ".

\section{Material and Methods}

Classroom Action Research (CAR) is one of the efforts that teachers can do to improve the quality of the roles and responsibilities of teachers, especially in the management of learning. CAR is part of the teacher's 
professional ability. CAR is a scientific activity that is a systematic and empirical thought process in an effort to solve a problem that is the problem of the learning process faced by the teacher himself in carrying out the main task of teaching (Sanjaya, 2013).

The place of this research is in Aisyiyah Kindergarten 2019/2020 Academic Year in the middle of a village located at Jl Karya Bersama RT. 19 Makmur Mulia Village Satui District Tanah Bumbu Regency, South Kalimantan Province. The subject of the study was group A which consisted of 15 children consisting of 6 girls and 9 boys.

In accordance with the type of research chosen, namely classroom action research, the researcher uses the action research model from Kemmis and Mc Taggart, which consists of four components, namely a) planning (planning), b) implementation (acting), c) observation (observing), and d) reflection (reflecting) (Kemmis \& McTaggart, 1992).

Data analysis through the activities of teachers, children and the results of the development of children's cognitive abilities. Indicators of success in this study are considered successful if the teacher's activity reaches a score with a range of scores between 26-33 with a very good category, children's activity reaches $\geq 80 \%$ with a very active category and on the child's developmental outcomes when the child's cognitive abilities increase in the learning process that reaches $\geq$ $80 \%$ or get $\star \star \star \star$.

\section{Results and Discussion}

Based on the results of this study in the first meeting of teacher activities scored 26 with the category "Good", the second meeting scored 28 with the category "Good". The 3rd meeting got a score of 35 in the "very good" category and the 4th meeting got a score of 36 in the "very good" category based on these data it can be concluded that the teacher's activities from the first meeting to the fourth meeting can be categorized very well so that teaching ability the teacher can be well honed.

In the results of research on children's activities show that student activity at the $1 \mathrm{st}$ meeting obtained a percentage of $53.92 \%$ categorized as quite active, while at the second meeting obtained a percentage of $63.33 \%$ active categorized. At the $3 \mathrm{rd}$ meeting, it got $82.5 \%$ percentage which was categorized as very active while at the 4 th meeting it got a percentage of $87.5 \%$ which was categorized as very active.

Based on the acquisition of these data it can be concluded that the child's activities are increasingly honed and formed when the child in the 4 th meeting is categorized as very active. thus $87.5 \%$ are included in the range of $82 \%$ $100 \%$ with very active criteria. The achievement of children's activity in children's cognitive development uses a combination of picture and picture learning models, talking sticks, conversational methods, demonstrations and number card media. It can be concluded that each meeting has an increase in children's activities so that the child will inevitably develop as they continue to be applied in learning and make the learning process interesting and enjoyable.

On the results of cognitive abilities results of Children at the first meeting to get a percentage of $55 \%$ categorized began to develop, while at the second meeting obtained a percentage of $69.44 \%$ categorized Developing. At the 3rd meeting, it got $82.22 \%$ percentage which was categorized as developing very well while at the 4 th meeting it was getting a percentage of $83.88 \%$ which was categorized as developing very well.

Based on the acquisition of these data it can be concluded that the development of children's cognitive abilities is increasingly honed and formed when the child in the 4th meeting that is categorized as developing very well with a percentage of $83.88 \%$ achievement of the development of children's cognitive abilities in the learning process using a combination of learning models picture and picture, talking sticks, conversational methods, demonstrations and number card media develop very well.

Based on the results of the class action research conducted, the use of picture and picture learning models, talking sticks, conversational methods, demonstrations and number card media have successfully improved learning in Aisyiah Kindergarten in group A well. In addition, the use of visual aids 
for teaching young learners also can help them to improve their vocabulary (Barania, Mazandaranib, \& Rezaiec, 2010). Since pictures can attract students' attention, using a picture book to teach young learners also can improve young learners' literacy skills (Kraayenoord \& Paris, 1996). Since young learners in this era are categorized into digital native, teaching them using technology-enhanced gadget that can play audio visual materials also can help them to concentrate more and make the teaching and learning process more interactive (Gonzalez-Acevedo, 2016). Furthermore, the use of technology can help students to improve their comprehension (Dalle \& Ariffin, 2018).

This can be seen in the development of learning at each meeting, where at the meeting 1 teacher only got a score of 26 in the Good category, then at the meeting 2 teachers only got a score of 28 in the Good category, followed at the meeting 3 teachers began to score 35 in the Very Good category, and finally at the 4th meeting successfully increased by reaching the category of Very Good with the acquisition of a score of 36 .

\section{Teacher's Activity}

From the learning activities carried out by the teacher as much as 4 times the meeting in developing children's cognitive abilities in recognizing numbers and symbol numbers can be concluded that at the 4th meeting teacher activities in the implementation of learning activities have achieved optimal results.

The teacher is an individual who deals directly with students through a process of instructional interaction as a vehicle for the learning process (Aslamiah, 2016). According to Suriansyah et al. (2009) a teacher is expected to be able to provide a good environment to be able to foster students' development optimally in the learning process.

The learning done by the teacher runs optimally because the teacher at each meeting always makes reflections so that from the reflection the teacher knows the deficiencies that should not be done at the next meeting, the teacher also masters the learning model better so that the learning carried out runs optimally. Learning also does not escape from the role of the teacher providing learning material to children. The role of teachers helps children to acquire communication skills, solve problems, and resolve conflicts (Suriansyah \& Aslamiah, 2011).

Improving the quality of learning and improving learning outcomes by developing better learning plans and in the form of mastering the weaknesses of the implementation carried out as well as regulating learning activities related to learning activities in early childhood suggests that basically concrete curriculum development in the form of a set of plans that contain a number of learning experiences while playing carried out in early childhood in order to achieve the competencies that must be achieved by children (Sujiono, 2013).

Learning is directed at the development and refinement of the potential abilities possessed such as language, socio-emotional, motor, and intellectual abilities. For this reason, learning at an early age must be designed so that children feel less burdened in achieving their development tasks (Isjoni, 2014).

Activities can be specifically designed to promote cooperative behavior in the classroom as well as learning centers. For kindergarten children cooperative learning can make it more free to be creative. The increase in teacher activity is influenced by the way the teacher guides children in learning, especially when using models, using media, and managing class well and directed.

The success of PAUD learning is based on the implementation of educators in organizing and managing learning such as the implementation of learning, procurement and guidance of experts, the utilization of the environment as a source of learning and the development and structuring of policies, this can be seen from the utilization of the environment, both the physical and social environment and also provides facilities and adequate infrastructure for the benefit of children's learning and play (Mulyasa, 2014). Educators should be able to create a new learning atmosphere so that children are not bored and fed up when receiving learning and 
he use of current technology can be a good idea in making the learning activities more fun (Baharuddin \& Dalle, 2017).

When viewed from the research that I did using a combination of models, methods and media that is a combination of the Learning Model picture and picture, talking sticks, conversational methods, demonstrations and media card numbers on cognitive aspects in matching the numbers and symbols of teacher activity at meetings 1 gets a score of 26 with a pretty good category and at the end of the meeting 4 a score of 36 with a very good category means more progress compared to before. The creation of a learning environment that can support the effectiveness and efficiency of children's learning is inseparable from the role of the teacher as a person who manages a pleasant learning environment for children. The teacher as an element that directly involved in the learning process with good children must know correctly and effectively the tasks and work that must be mastered in managing the learning environment available in the school environment (Sakerebau, 2018).

Parents or educators must understand the child's development so they can develop their potential optimally. Understanding is important for several reasons namely, childhood is a period of rapid development and changes occur in many aspects of development, childhood experiences have a strong influence on subsequent development, knowledge about children's development can help them develop themselves, and solve the problems they face, and through understanding of the factors that influence children's development, can be anticipated with various efforts to facilitate these developments, both in the family, school and community (Yusuf, 2017).

Since the exposure of current technology cannot be avoided, parents' engagement in controlling in the use of digital technologies of young learners, because young learners are normally more motivated studying using digital technologies (Strouse, Newland, \& Mourlam, 2019). Those parents who can scaffold their children through technologies will get more benefits from the use of current digital technologies (Dias, et al., 2016). Digital technologies may bring positives things to the development of young learners, however parents should engage, communicate with their children about the use of digital technologies, and guide their children so that they can learn through digital technologies (Coppock \& Gillett-Swan, 2016). Improving literacy skills for young learners, for example, can be done through digital technology (Ozturk \& Ohi, 2018). Teaching story for young learners through e-book using digital technology is proven to have a positive impact on young learners' literacy skills and motivation (Reich, et al., 2019).

\section{Children's Activities}

Based on research conducted at each meeting experienced an increase in children's activity, at the meeting 1 child obtained a percentage of $52.2 \%$ with the category of quite active. At the 2nd meeting, children's activity increased with a percentage of $63.3 \%$ with the active category. Then at meeting 3 the increase in children's activity is getting better by obtaining $82.5 \%$ with the very active category. And at meeting 4 the increase in children's activity occurred as expected by obtaining a percentage of $87.5 \%$ in the very active category. This is due to the teacher's optimal learning and learning from the deficiencies that exist in the next meeting so that what is expected at this 4th meeting is successful, namely by achieving a percentage of success.

Early childhood is a generalization of the nation's successors in the future. Children are born with their potential and intelligence. To optimize the potential of children, adults and the environment around children must be able to provide appropriate stimulation and in accordance with the needs and stages of child development.

Various studies conducted by experts concluded that children's education from an early age can improve performance and increase productivity of adult work (Yusuf, 2017). Early childhood is a golden age that is very important to provide stimulus to the child's development. Childhood is a time to lay the first foundation in developing physical, motor, cognitive, language, social-emotional abilities, self-concept, discipline, art, morals, and religious values. Therefore, conditions and 
stimulation are needed in accordance with the needs of children in order to achieve optimal growth and development of children (Yusuf, 2017).

The world of play is the world of children. Through play children can learn many things, without realizing it and without feeling burdened. Through play children can get to know the rules, socialize, position themselves, organize emotions, tolerance, cooperation, succumbing, sportsmanship and other positive attitudes as well as the children's mental, language, and motor intelligence also develops although sometimes their selfishness also grows when playing (Mulyasa, 2014).

Early childhood is most happy in terms of play, however there are ways to play there is learning in the game. So let the child play at will not limit him, because through playing the child learns. playing as a direct or spontaneous activity, in which a child interacts with other people, objects around him, carried out happily (happily), on his own initiative, using imaginary (imaginative) powers, using the senses, and all parts of his body (Latif, Zulkhairina, Zubaidah, \& Afandi, 2016). Though games young learners may learn many new things. Even computer games are also reported may assist young learners to learn a foreign language (Turgut \& İrgin, 2009). Video gamebased instruction is proven to have a positive impact on students' English vocabulary (Thompson \& Gillern, 2020). For alpha generation, learning through virtual competition preforms better than learning though real competition (Chen \& Chang, 2020). Furthermore, the use of game sound in game-based learning environment also has a positive impact on students' motivation and engagement during the teaching and learning process (Byun \& Loh, 2015). Virtual game based-learning is also reported that it can improve students' vocabulary, learning autonomy and collaboration (Tseng, Liou, \& Chu, 2020). Studying through game can improves young learners' motivation to study (Yang, Chang, Hwang, \& Zou, 2020).

Therefore educators should be able to provide an atmosphere of learning while playing, because that's how children learn. Early childhood learning adheres to the approach of playing while learning or learning while playing (Sujiono, 2013). By playing, children discover and learn new things or skills and learn when to use these skills, as well as satisfy their needs. Through play, the physical child will be trained, cognitive abilities and emotional social abilities of children in interacting with others will develop. Curiosity and a strong enthusiasm for everything are prominent features in children, especially children aged 4-6 years. Children have a strong attitude of adventure will pay attention to, talk about or ask questions about various things that could be seen or heard (Susanto, 2011).

The teacher should be able to provide a learning method that provides broad opportunities for children to be active and creative both physically and mentally as well as in the learning model picture and picture, talking sticks, methods of conversing, demonstrations and media card numbers in the implementation of this motivation children in learning will arise because the media / learning resources that are presented are very interesting children's attention.

Relevant research on picture and picture learning models, talking sticks, conversational methods, demonstrations and number card media that have been done by previous researchers, including Parwati, Parmiti, and Jampel (2013) which aims to find out, increase cognitive abilities students after the application of the picture and picture learning model assisted by group B picture cards in the second semester of the 2012/2013 school year 2012/2013 kindergarten Widya Brata Mengwi. Moreover, the use of picture book with time pressure activity can create young learner creativity (Tsai, Chang, \& Lo, 2018). The analysis shows that the average percentage of children's cognitive development in the first cycle of $53.00 \%$ is in the very low category and the average percentage of children's cognitive development in the second cycle $93.00 \%$ is in a very high category. This indicates an increase in the average the percentage of children's cognitive development from cycle I to cycle II is $40 \%$ and is in the active category.

Through a combination of picture and picture learning models, talking sticks, 
conversational methods, demonstrations and number card media, children are able to match numbers and symbols exactly. The results of the development of cognitive abilities in group A children in Kindergarten Aisyiyah Satui District through a combination of models above the child can develop.

\section{Results of Cognitive Development}

Based on the research results of cognitive development of children at meeting 1 as many as $53 \%$ of children with criteria $<\star \star$ and as many as $47 \%$ of children with criteria $>\star \star \star$. Increased at meeting 4 by $13 \%$ children with the criteria $<\star \star$ and as many as $87 \%$ children with the criteria $>\star \star \star$. With the results at the 4th meeting, this means that the results of children's cognitive development have reached indicators of success.

Improvements to children's cognitive development outcomes are caused because in the learning process the teacher applies childcentered learning both from the use of picture and picture models, talking sticks, conversational methods, demonstrations and number card media where the implementation of learning is very helpful for children to build their own understanding based on what he has experienced / learned.

Active learning is learning that is applied to early childhood which is done by giving questions to children then allowing children to think or ask themselves, so the learning outcomes obtained are constructions of children's thinking (Sujiono, 2013).

Sujiono also revealed that basically children have the ability to build and create their own knowledge, children's direct involvement in learning is very important.

This opinion was also strengthened by (Masitoh, 2011) who argues that early childhood learning outcomes prioritize learning while playing and are oriented towards child development so that it can provide opportunities for children to actively carry out learning activities and in developing all aspects of their development.

Masitoh also revealed that the success of learning activities in kindergarten can be seen from the success of the optimal early childhood learning process both from the achievement of growth and development in early childhood.

In this study, researchers tried to examine the results of cognitive development in children using the learning model picture and picture, talking sticks, conversational methods, demonstrations and media card numbers, especially on the material matching numbers and symbols of numbers which is evidenced by the use of the learning combination results Children's cognitive development can increase as stated by Piaget in (Nuryanti, 2008), the rate of cognitive development in early childhood is in a concrete operational period at which time the child has reached a certain logical structure that allows them to form several operations mental, but still limited to concrete objects.

The application of picture and picture models assisted by number card media to improve children's cognitive development in kindergarten Buana Sutha Nugraha Salemadeg showed an increase in cognitive development in group B in the first cycle $61.6 \%$ in the category low, in the second cycle increased by $82.95 \%$ in the high category (Mertadi, Pudjawan, \& Raga, 2014).

Variation of Demonstration Learning Models in Expressing Images in Detail Using Direct Practice Methods in Early Childhood shows that at meeting 1 showed a value of $33.33 \%$ with the category not yet developed, at meeting 2 showed a value of $73,33 \%$ with the category of developing as expected, at the 3rd meeting increased to $93.33 \%$ with the category of developing very well (Darmiyati \& Amalia, 2017) . Implementation of using a combination of models using a model's picture and picture, Talking Stick, the method of conservation, demonstration with the numbered symbols media. 
Table 1. Comparison of results from observations of teacher activity, child activity, and child development outcomes

\begin{tabular}{lcccc}
\hline \multirow{2}{*}{ Development } & \multicolumn{4}{c}{ Cycle } \\
\cline { 2 - 5 } & Meeting 1 & Meeting 2 & Meeting 1 & Meeting 2 \\
\hline Teacher & & & & \\
activity & $65 \%$ & $70 \%$ & $87 \%$ & $90 \%$ \\
Child activity & $52 \%$ & $63 \%$ & $85 \%$ & $87 \%$ \\
Development & $47 \%$ & $66 \%$ & $70 \%$ & $87 \%$ \\
Outcomes & & & & \\
\hline
\end{tabular}

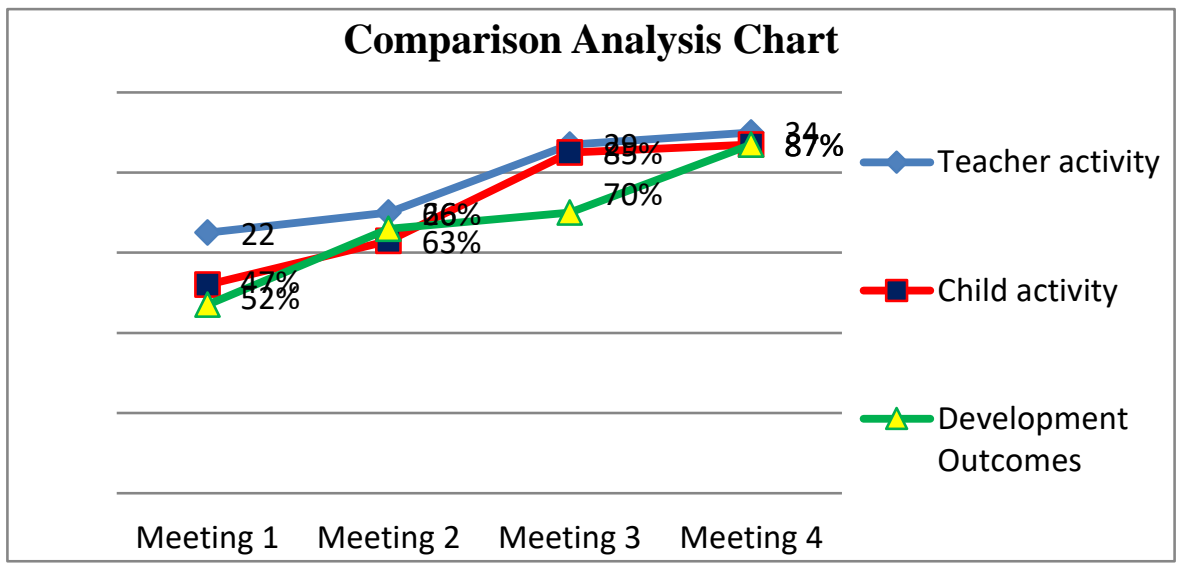

Figure 1. Comparation Analysis Chart

\section{Conclusion and Recommendation}

Based on the findings obtained from the results of Classroom Action Research (CAR) in the field of development of cognitive aspects in matching numbers and symbol numbers using the learning model picture and picture, talking stick, talking method, demonstration and number card media, namely; (1) Teacher activities in developing early childhood cognitive in matching numbers and symbol numbers using a combination of picture and picture learning models, talking sticks, conversational methods, demonstrations and number card media in Children Group A Kindergarten Aisyiyah Kecamatan Satui are in accordance with the steps the learning model steps used and achieving the criteria very well. (2) Children's activities in the development of cognitive aspects of early childhood in matching numbers and symbol numbers using a combination of Picture and Picture Learning Models, talking sticks, conversational methods, demonstrations and number card media in Children Group A Kindergarten Aisyiyah Kecamatan Satui are in accordance with the learning model steps used and achieving the criteria are very good. (3) Child development activities in recognizing numbers and symbols using a combination of picture and picture learning models, talking sticks, conversational methods, demonstrations and number card media in Aisyiyah Kindergarten Group A Kindergarten Children Kecamatan Satui is in accordance with the steps of the learning model used and achieves very good criteria.

Based on the results of the study, the following discussion and conclusions can be submitted: (1) For principals, it is recommended that they provide guidance and direction to all teachers to better optimize the use of learning methods and models in order to develop the quality of learning in TK Aisyiyah Kecamatan Satui. (2) For teachers, through this research, it is expected to improve the professionalism of the teacher, the teacher in providing learning activities that are interesting, active, innovative, creative, and fun for early childhood. (3) For the next researcher, it is expected that the results of this class action research can be a reference in conducting research on developing 
cognitive aspects (matching numbers and symbol numbers) using various media using a combination of picture and picture learning models, talking sticks, conversational methods, demonstrations and number card media.

\section{Acknowledgment}

Thank you to the head of the program, the secretariat and the lecturers of the Graduate Program of Early Childhood Teacher Education, Universitas Lambung Mangkurat Banjarmasin, who have provided input and suggestions for writing this article and thank you also to the Principal, Kindergarten Teacher Aisyiyah Kecamatan Satui for helping with the smooth running of this research. May we all always be in the Blessing of Allah SWT. Amen.

\section{References}

Amalia, E. R., \& Khoiriyati, S. (2018). Effective learning activities to improve early child-hood cognitive development. AlAthfal Journal of Children's Education, 4(1), 103-112. doi:http://dx.doi.org/10.14421/al-athfal.2018.41-07

Aqib, Z. (2014). Media Models and Contextual Learning Strategies (Innovative). Bandung: Yrama Widya.

Aslamiah. (2011). Application of habitualizing children's behavior through learning and playing activities in Alhamid Kindergarten Banjarmasin. Jurnal Paradigma, 5(10), 33-44.

Baharuddin, \& Dalle, J. (2017). Interactive Courseware for Supporting Learners Competency in Practical Skills. TOJET: The Turkish Online Journal of Educational Technology, 16(3), 1-13.

Baiti, N., Metroyadi, \& Wahyu. (2019). Parenting, SocioEconomic, and Parental Communication Against Children's Language Ability. j-K6EM, 2(1), 58-63.

Barania, G., Mazandaranib, O., \& Rezaiec, S. H. (2010). The effect of application of picture into picture audio- visual aids on vocabulary learning of young Iranian ELF learners. Procedia Social and Behavioral Sciences, 2(2), 5362-5369. doi:https://doi.org/10.1016/j.sbspro.2010.03.874

Byun, J. H., \& Loh, C. S. (2015). Audial engagement: Effects of game sound on learner engagement in digital game-based learning environments. Computers in Human Behavior, 46, 129-138. doi:https://doi.org/10.1016/j.chb.2014.12.052

Chen, S. Y., \& Chang, Y.-M. (2020). The impacts of real competition and virtual competition in digital game-based learning. Computers in Human Behavior, 104, 1-14. doi:https://doi.org/10.1016/j.chb.2019.106171

Coppock, V., \& Gillett-Swan, J. K. (2016). Children's rights in a 21st-century digital world: Exploring opportunities and tensions. Global Studies of Childhood, 6(4), 369-375. doi: https://doi.org/10.1177/2043610616676025

Dalle, J., \& Ariffin, A. M. (2018). The Impact of Technologies in Teaching Interaction Design. Journal of Advaced Research in Dynamical and Control System, 04(special issue), 17791783.

Darling-Hammond, L., Flook, L., Cook-Harvey, C., Barron, B., \& Osher, D. (2020). Implications for educational practice of the science of learning and development. Applied Developmental Science, 24(2), 97-140. doi:https://doi.org/10.1080/10888691.2018.1537791

Darmiyati, \& Amalia, S. (2017). Variations of demonstration learning model in expressing images in detail using direct practice method in early childhood. J-K6EM, 1(1), 13-19 eprints.ulm.ac.id/5966/.

Dias, P., Brito, R., Ribbens, W., Daniela, L., Rubene, Z., Dreier, M., \& Chaudron, S. (2016). The role of parents in the engagement of young children with digital technologies: Exploring tensions between rights of access and protection, from 'Gatekeepers' to 'Scaffolders. Global Studies of Childhood, 6(4), 414-427. doi:https://doi.org/10.1177/2043610616676024

Fatmasari, D., Darmiyati, \& Sulaiman. (2015). The use of direct instruction models in combination with the team game tournament (TGT) to improve learning outcomes of the properties of space building in class V SDN Kuin Cerucuk 3 Banjarmasin. Paradigm Journal, 10(1), 1-8.

Gonzalez-Acevedo, N. (2016). Technology-enhanced-gadgets in the Teaching of English as a Foreign Language to Very Young Learners. Ideas on Implementation. Procedia Social and Behavioral Sciences, 232, 507-513. doi:https://doi.org/10.1016/j.sbspro.2016.10.070

Hadi, S., \& Kasum, U. (2015). Understanding of the mathematical concepts of junior high school students through the application of cooperative learning models of pair check (pair cheiks). Journal of Mathematics Education, 3(1), 5966.

Isjoni. (2014). Early childhood learning models). Bandung: Alfabeta.

Kemmis, S., \& McTaggart, R. (1992). The action research planner. Victoria: Deakin University.

Kraayenoord, C. E., \& Paris, S. G. (1996). Story construction from a picture book: An assessment activity for young learners. Early Childhood Research Quarterly, 11(1), 41-61. doi:https://doi.org/10.1016/S0885-2006(96)90028-9

Latif, M., Zulkhairina, Zubaidah, R., \& Afandi, M. (2016). A new orientation to early childhood education . Jakarta: Prenada Media Group BP .

Masitoh. (2011). Kindergarten learning strategies. Jakarta: Open University. 
Maufur, H. F. (2009). A million fun teaching skills. Jakarta: PT. Sindur Press.

Mertadi, A., Pudjawan, I., \& Raga, I. (2014). The application of the make a match model is assisted by number card media to improve children's cognitive development in kindergarten Buana Sutha Nugraha Selemadeg. e-Journal PG-PAUD Ganesha University of Education, 2(1), 1-10.

Ministry of National Education. (2009). Minister of national education regulation No. 58 of 2009 concerning early childhood education standards. Jakarta: Ministry of National Education of Indonesian Republic.

Moeslichatoen. (2004). Teaching methods in kindergartens. Jakarta: Rineka Cipta.

Mulyasa. (2014). Development and implementation of the 2013 curriculum. Jakarta: Remaja Rosda Karya.

Musfiroh, T. (2012). development of multiple intelligences. Tangerang: Open University.

Nuryanti, L. (2008). Child psychology. Jakarta: PT Indeks.

Ozturk, G., \& Ohi, S. (2018). Understanding young children's attitudes towards reading in relation to their digital literacy activities at home. Journal of Early Childhood Research, 16(4), 393-406. doi:https://doi.org/10.1177/1476718X18792684

Parwati, N. N., Parmiti, D. P., \& Jampel, I. N. (2013). The application of picture and picture learning with the help of pictorial number card media can enhance cognitive development. Journal of Early Childhood Education, 1(1), 110. doi:http://dx.doi.org/10.23887/paud.v1i1.1041

Pradina, Y. A., \& Hastuti, W. D. (2017). The Effect of Picture and Picture Learning model towards science outcomes for students with hearing impairment in the class VII. Journal of ICSAR, 1(2), 145-149. doi:http://dx.doi.org/10.17977/um005v1i22017p145

Reich, S. M., Yau, J. C., Xu, Y., Muskat, T., Uvalle, J., \& Cannata, D. (2019). Digital or print? a comparison of preschoolers' comprehension, vocabulary, and engagement from a print book and an e-book. American Educational research Association Open, 5(3), 1-16. doi:https://doi.org/10.1177/2332858419878389

Safitri, M. E., Ahmad, K., \& Saleh, M. (2018). Development Of Child Independence Through Model Picture and Picture, Examples Non Examples Model and Practical Method Directly Activities of Learning Practical Life In Group B Kasih Ibu Kindergarten, Banjarmasin, Indonesia. European Journal of Education Studies, 5(7), 64-80.

Sakerebau, J. (2018). Understanding the role of educational psychology for learning. BIA Journal of Christian Theology and Contextual Education, 1(1), 96-111. doi:https://doi.org/10.34307/b.v1i1.22
Sanjaya, W. (2013). Standardized educational process oriented learning strategies. Jakarta: Prenada.

Strouse, G. A., Newland, L. A., \& Mourlam, D. J. (2019). Educational and fun? parent versus preschooler perceptions and co-use of digital and print media. American Educational Research Association, 5(3), 1-14. doi:https://doi.org/10.1177/2332858419861085

Sujiono, Y. N. (2013). Basic concepts of early childhood education.Jakarta: PT Indeks.

Suriansyah, A., \& Aslamiah. (2011). Education foundation. Banjarmasin: Comdes.

Suriansyah, A., \& Mahriati, S. (2016). Improving learning outcomes of the concept of the properties of space building with the two stay two stray learning model and realia media for fifth grade students of SDN Pengambangan 8 Banjarmasin. Paradigm Journal, 11(2), 6-10.

Suriansyah, A., Aslamiah, Noorhafizah, \& Sulaiman. (2009). Learning strategies. Banjarmasin: Lambung Mangkurat University.

Susanto, A. (2011). Early childhood development: Introduction to various aspects. Jakarta: Kencana.

Thompson, C. G., \& Gillern, S. (2020). Video-game based instruction for vocabulary acquisition with English language learners: A Bayesian meta-analysis. Educational Research Review, 30, 1-13. doi:https://doi.org/10.1016/j.edurev.2020.100332

Tsai, C.-Y., Chang, Y.-H., \& Lo, C.-L. (2018). Learning under time pressure: Learners who think positively achieve superior learning outcomes from creative teaching methods using picture books. Thinking Skills and Creativity, 27, 55-63. doi:https://doi.org/10.1016/j.tsc.2017.11.003

Tseng, W.-T., Liou, H.-J., \& Chu, H.-C. (2020). Vocabulary learning in virtual environments: Learner autonomy and collaboration. System, 88, 1-17. doi:https://doi.org/10.1016/j.system.2019.102190

Turgut, Y., \& İrgin, P. (2009). Young learners' language learning via computer games. Procedia - Social and Behavioral Sciences, 1 11), 760-764. doi:https://doi.org/10.1016/j.sbspro.2009.01.135

Wahyudi, M. D. (2015). Implementasi authentic assessment di PAUD. Prosiding SEMNAS PS2DMP ULM. 1, pp. 17-26. Banjarmasin: rumahjurnal.net.

Yang, Q.-F., Chang, S.-C., Hwang, G.-J., \& Zou, D. (2020). Balancing cognitive complexity and gaming level: Effects of a cognitive complexity-based competition game on EFL students' English vocabulary learning performance, anxiety and behaviors. Computers \& Education, 148, 1-17. doi:https://doi.org/10.1016/j.compedu.2020.103808

Yusuf, S. (2017). Child and adolescent developmental psychology. Jakarta: PT Remaja Rosdakarya. 